\title{
The Evaluation of Countercyclical Policy Implementation in Facing the Impact of the Spread of COVID-19 (Study on Central Kalimantan Bank Pension Fund)
}

\author{
Ike Trisia \\ Postgraduate Program in Economy Sciences, Universitas Palangka Raya, Indonesia \\ ketrism46@gmail.com
}

\begin{abstract}
This research is a qualitative descriptive study that aims to determine the implementation of countercyclical policies that have been implemented by the Central Kalimantan Bank Pension Fund in dealing with the impact of the spread of COVID-19. The data processed in this study were obtained using interview techniques and supplemented with secondary data which was accessed from various sources. The results of this study indicate that the Bank Kalteng Pension Fund has implemented the provisions of the countercyclical policy as in the Financial Services Authority Circular Letter Number S-10 / D.05 / 2020. In implementing the countercyclical policy, the Bank Kalteng Pension Fund implements the Relaxation of Periodic Report Submission, Implementation of Fit and Proper Tests through Video Converence and Investment Shift to Low Risk Investments.
\end{abstract}

Keywords

œOMD-19; countercyclical policy, pension fund

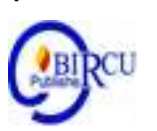

\section{Introduction}

Corona Virus Disease 2019 (COVID-19) has shocked the whole world, as the case of this new virus outbreak continues to increase and has an impact in various aspects including social, economic and community welfare aspects. The World Health Organization (WHO) as the world health organization on March 11, 2020 declared Corona Virus Disease 2019 (COVID-19) a Global Pandemic. In December, the city of Wuhan was reported as the place where the Covid-19 outbreak was originally discovered and then spread to all parts of the world. Including in Indonesia, from online media kompas.com 2 of March 2020, The President of the Republic of Indonesia, Mr. Joko Widodo, stated that the spread of Covid-19 in Indonesia began on March 2, 2020, after the discovery of the first case of Corona Virus Disease 2019 (COVID-19) infection in Indonesia. The spread of the Covid-19 outbreak in Indonesia continues to increase, as based on the worldometers report regarding the case of the corona virus on August 16, 2020, the State of Indonesia is ranked 23 in the world with a total of 139,549 positive cases of positive patients, 93,103 recovered patients and the number of patients died was 6,150 people. Meanwhile, in the scope of Southeast Asia, Indonesia is in second place with the most positive cases of corona virus after the Philippines.

The increased case of COVID-19 has affected the world economy including Indonesia. The COVID-19 pandemic that has been established by the UN, affects the transportation, tourism, trade, health and other sectors. The "lock down" policy is taken by various countries to prevent further spread of covid-19, so that economic activities are hindered and put pressure on the world's economic growth in the future including Indonesia's economic growth. The Government encourages the Ministry and institutions $(\mathrm{K} / \mathrm{L})$ as well as the local government (PEMDA) to accelerate spending primarily on the first quarter 2020 schedule. This was done to reduce the pressure on Indonesia's economic growth due to the pandemic 
Covid-19, as well as a decline in commodity prices (Kementerian Keuangan RI, 2020a). (Susilawati et al, 2020).

The large number of countries that experienced the Covid-19 case made the World Health Organization (WHO) raise the Covid-19 case from an epidemic to a pandemic (Ekarina, 2020). The rising status of Covid-19 from an epidemic to a pandemic has made many countries including Indonesia undertake various practices of protection and supervision of the region and human interaction in it with various mechanisms including; social distancing, physical distancing, regional quarantine to lockdown mechanisms. (Saleh, 2020)

The current COVID-19 lockdown situation has had an impact on people's connectedness by limiting their allowed behaviours, resulting in a negative impact on people's mental health and well-being on the whole (Oe and Week 2020). The enhancement of human interaction and networking to sustain people's mental health has been on the emergent agenda during the current COVID-19 situation.

Given that the 2019 Corona Virus Disease (COVID-19) pandemic also has an impact on the economic aspect, this pandemic has had a negative impact on various industrial sectors, including the financial industry sector, namely Pension Funds. As the impact of the Covid-19 pandemic has suppressed investment performance in the pension fund industry, namely the return on investment (ROI) which shows a downward trend. Based on the report from the Financial Services Authority (OJK), it is recorded that the Return on Investment (ROI) obtained by Pension Funds up to the period of May 2020 is 2.55\% and decreased when compared to the acquisition of the same period in 2019 which was 3, 22\%. In Employer Pension Fund (DPPK) with Defined Benefit Pension Program (PPMP), The return on investment (ROI) up to the period of May 2020 was $2.75 \%$ which also shows a downward trend when compared to the return of investment (ROI) for the same month period in 2019 of $3.27 \%$. Then, the Financial Institution Pension Fund (DPLK) also experienced a downward trend for the return on investment (ROI), from $3.16 \%$ to $2.23 \%$. The same thing also happened to the Employer Pension Fund (DPPK) with a Defined Contribution Pension Program (PPIP), where the return on investment (ROI) experienced a downward trend from $3.13 \%$ to $2.23 \%$. Then, the Financial Institution Pension Fund (DPLK) also experienced a downward trend for the return on investment (ROI), from $3.16 \%$ to $2.23 \%$. The same thing also happened to the Employer Pension Fund (DPPK) with a Defined Contribution Pension Program (PPIP), where the return on investment (ROI) experienced a downward trend from $3.13 \%$ to $2.23 \%$. Then, the Financial Institution Pension Fund (DPLK) also experienced a downward trend for the return on investment (ROI), from $3.16 \%$ to $2.23 \%$. The same thing also happened to the Employer Pension Fund (DPPK) with a Defined Contribution Pension Program (PPIP), where the return on investment (ROI) experienced a downward trend from $3.13 \%$ to $2.23 \%$.

Minimizing risks and seeking opportunities for recovery or rebound are the right responses to take in the face of the impact of the Covid-19 pandemic, considering that the pressure from the outbreak can have a direct or indirect impact on financial system stability and economic growth, including the performance and capacity of funding institutions. retire in Indonesia. In the financial services industry, namely the Pension Fund, the Financial Services Authority (OJK) as the supervisory agency issued several relaxation policies that were used as a solution in dealing with the crisis impacted by the spread of the Covid-19 outbreak.

For pension funds, starting from March 2020, at least 2 (two) relaxation policies have been issued by the Financial Services Authority (OJK), as the second policy is a complement to the previous policy. The Countercyclical Policy is a relaxation policy referred to and 
issued by the Financial Services Authority (OJK) with the aim of maintaining stability in the Pension Fund as one of the non-bank financial services industry. In S-10 / D.05 / 2020 concerning Countercyclical Policy, the Chief Executive of OJK's Non-Bank Financial Industry Supervisor, Mr.Riswinandi, said that there were several provisions made to maintain the stability of the Pension Fund industry. The first provision is an extension of the periodic reporting deadline.

In the 88th Edition of the Pension Fund Info Magazine (May-June 2020) entitled Measuring the Impact of COVID-19 on the Banking Industry, the Managing Director of the RNI Pension Fund, Budi Ruseno said that the relaxation policy that has been implemented by the Financial Services Authority (OJK) in a countercyclical policy is sufficient. assisting pension funds, including in assessing fixed income securities and in meeting the adequacy of funding. Apart from that, Budi Ruseno also argued that the policy had also helped pension funds in administrative terms. Meanwhile, the Managing Director of the Jasaraharja Pension Fund, Riswandi said that the relaxation that has been given by the Financial Services Authority is sufficient to assist Pension Funds in managing and calculating net assets on bonds and SUN and also assisting in fulfilling the obligation to submit reports to the authorities.

Minimizing risks and seeking opportunities for recovery or rebound with the aim of financial stabilization are things pension funds in Indonesia can do, namely by referring to the policy on the impact of the spread of Covid-19 that has been issued by the Financial Services Authority (OJK) for pension funds, namely implementation of the Countercyclical Policy.

\section{Review of Literatures}

\subsection{Definition of Pension Funds}

Based on the Law of the Republic of Indonesia Number 11 of 1992, the Pension Fund is a legal entity that manages a program and promises a pension benefit. Like pension benefits, in this case, it is a periodic payment activity that is paid to participants who have entered retirement, according to and based on pension fund regulations. Pension Fund can also be interpreted as an institution that carries out management activities in the form of a pension program, with the aim of providing welfare for employees in the form of pension benefits (Setyo Wijayanto, 2015).

Referring to the Law of the Republic of Indonesia No.11 of 1992, there are 2 (two) types of Pension Fund, namely Employer Pension Fund (DPPK) and Financial Institution Pension Fund (DPLK). As the Employer Pension Fund (DPPK) is a pension fund established by an individual or a legal entity that employs employees to be participants in the pension program in the pension fund, with the aim of the interests of part or all of the employees as participants and which creates obligations for the employer. In this case, the pension programs administered by the Employer Pension Fund (DPPK) are the Defined Benefit Pension Program (PPMP) and the Defined Contribution Pension Program (PPIP). Then, the Financial Institution Pension Fund (DPLK) is a pension fund established by commercial banks or life insurance companies for individuals, that is, among others, employees and independent workers who are separated from the Employer Pension Fund (DPPK), namely for employees of the bank or life insurance company concerned. In this case, the pension program administered by the Financial Institution Pension Fund (DPLK) is the Defined Contribution Pension Program (PPIP). 
As the Pension Program is any program that aims to provide pension benefits for its participants. Defined Benefit Pension Program (PPMP) is a pension program whose benefits are determined based on the Pension Fund Regulation (PDP) or other types of pension plans besides the Defined Contribution Pension Program (PPIP). Meanwhile, the Defined Contribution Pension Program (PPIP) is a pension program whose contributions are determined based on the Pension Fund Regulation (PDP) and all contributions and the proceeds from the development of these contributions will be recorded in the accounts of each pension fund participant as pension benefits.

\subsection{Pension Fund Investment}

According to Khaerul and Herry (2017), investment is an excess of funds or other resources that are sacrificed or expended in the present with the aim of obtaining future benefits. Pension Fund Investment based on OJK Regulation Number 3 of 2015 concerning Pension Fund Investment is an activity or action carried out by Pension Fund Managers in the Context of developing funds that have been managed by the Pension Fund with the aim of the interests of pension fund participants. As with the types of investment funds directed at Pension Funds, including the following:

a. Savings in the Bank

b. Deposit on call at the Bank

c. Time deposit at the Bank

d. Certificate of deposit at the Bank

e. Securities issued by Bank Indonesia

f. Government Securities (SBN)

g. Shares listed on the Stock Exchange in Indonesia

h. Corporate bonds listed on the Indonesian Stock Exchange.

i. Mutual funds, which consist of:

1) Money market funds, fixed income mutual funds, balanced mutual funds and equity funds

2) Protected mutual funds, mutual funds with guarantees and index funds

3) Mutual funds in the form of limited participation collective investment contracts

4) Mutual funds whose shares or units are traded on a Stock Exchange in Indonesia

\section{j. MTN}

k. Asset-backed securities

1. Real estate investment funds take the form of collective investment contracts

$\mathrm{m}$. Stock options and futures contracts traded on a stock exchange in Indonesia

n. REPO

o. Direct investment both in Indonesia and abroad

p. Land in Indonesia

q. Buildings in Indonesia.

\subsection{Countercyclical Policy the Impact of Corona Virus Disease (COVID-19) Spread on Pension Funds}

Based on Circular Number S-10 / D.05 / 2020 signed by Mr. Riswandi as Chief Executive of the Non-Bank Financial Industry Supervisor (IKNB) on March 30, 2020, the Countercylical Policy is a policy as a result of the spread of Corona Virus Disease 2019 (COVID -19) for the Non-Bank Financial Services Institution (LJKNB) industry, which includes the Insurance Industry, Pension Funds, Financing Institutions and other Financial Services Institutions. As referring to Circular Number S-10 / D.05 / 2020 Year 2020, the countercyclical policy aimed at Pension Funds consists of several points of provisions, including the following: 
a. Extension of the deadline for submitting Periodic Pension Fund Reports to the Financial Services Authority (OJK) by referring to the information previously provided, namely through Letter Number S7 / D.05 / 2020 dated March 23, 2020.

b. The implementation of the fit and proper test of the main party of the Pension Fund is conducted online, namely through a video conference.

c. In the framework of calculating the Funding Ratio for Pension Funds with a Defined Benefit Pension Plan (PPMP), assets in the form of:

1) Corporate Bonds that have been listed on the Stock Exchange

2) Sukuk or Sharia Bonds listed on the Stock Exchange

3) Securities issued by the State of Indonesia

4) Sharia Securities issued by the State of Indonesia. As the assessment can be carried out based on the amortized value of acquisition, as long as it cannot cause the quality of funding in the Pension Fund to be higher than the quality of funding in the previous actuarial valuation.

d. Can postpone a maximum of 1 (one) year related to the implementation of life cycle fund provisions for Pension Funds that organize a Defined Contribution Pension Program (PPIP) or Pension Fund Participants whose 2 (two) to 5 (years) are entering retirement age.

Table 1. Relaxation of the Deadline for Obligation to Submit Periodic Reports for Pension Funds and Sharia Pension Funds

\begin{tabular}{|c|c|c|c|}
\hline Report Type & Report Period & $\begin{array}{l}\text { Deadline for Report } \\
\text { Submission Based on } \\
\text { Conditions }\end{array}$ & $\begin{array}{l}\text { Relaxation Deadline for } \\
\text { Report Submission }\end{array}$ \\
\hline \multirow[b]{3}{*}{ Monthly report } & March 2020 & April 10, 2020 & \multirow{3}{*}{$\begin{array}{l}\text { Extended } 14 \text { Working Days } \\
\text { (HK) from the deadline for } \\
\text { the expiry of the repor } \\
\text { submission obligation }\end{array}$} \\
\hline & April 2020 & 10 May 2020 & \\
\hline & May 2020 & 10 June 2020 & \\
\hline $\begin{array}{c}\text { Quarterly } \\
\text { Complaint } \\
\text { Service Report }\end{array}$ & March 31, 2020 & April 10, 2020 & $\begin{array}{l}\text { Extended } 14 \text { Working Days } \\
\text { (HK) from the deadline for } \\
\text { the end of the report } \\
\text { submission obligation. }\end{array}$ \\
\hline Annual report & $\begin{array}{c}\text { As of December } \\
31,2019\end{array}$ & April 30, 2020 & $\begin{array}{l}\text { Extended by } 2 \text { months from } \\
\text { the deadline for reporting } \\
\text { obligation to submit. }\end{array}$ \\
\hline
\end{tabular}

Source: Letter of the Chief Executive of IKNB Supervisor Number S-7 / D.05 / 2020 dated March 23, 2020

\section{Reseach Method}

This research is a type of qualitative research with a case study method of the Bank Kalteng Pension Fund as a Non-Bank Financial Services Institution Industry (LJNKB) which is affected by the Covid-19 Pandemic and is based on a circular letter. S-10 / D.05 / 2020 Year 2020 asked to implement the Countercyclical Policy as a form of policy for the impact of the spread of Corona Virus Disease 2019 (COVID-19). Conducting in-depth exploration of a program, event, process and activity of one or more research objects is what researchers do in using the case study method (Sugiyono, 2011). The cases reviewed by researchers are time and activity bound. Namely from January - June 2020. This study uses primary data obtained through direct interviews with informants related to the implementation of the Countercyclical Policy, namely the impact of the spread of Covid-19 for Pension Funds and 
secondary data, namely the internal provisions of the Pension Fund and laws and regulations applies regarding the implementation of countercyclical policies.

The data analysis technique used by the researcher is the Miles and Huberman analysis technique which includes several stages of analysis, namely data reduction, display data and a conclusion. As after researchers obtain data through direct interviews with informants, the data will be reduced so that researchers get a clear picture to support the achievement of research objectives, then the data display stage or data presentation and the last stage is the conclusion, namely drawing conclusions and verification (Sugiyono, 2011). Meanwhile, to check the validity of the data, the researcher used persistence enhancement techniques, namely in the form of reference materials and source triangulation. Persistence improvement aims to consistently seek interpretations in various ways, related to the tentative data analysis process (Moleong, 2016).

\section{Discussion}

Bank Kalteng Pension Fund is an Employer Pension Fund (DPPK) which organizes a Defined Benefit Pension Program (PPMP), as in this case Participants and Employers collect contributions / contributions together. Every employee who is 18 years old or over 18 years old or married and appointed as a permanent employee is a participant of the PT. Central Kalimantan Regional Bank Development Bank. As with Bank Kalteng Pension Fund Participation, in this case, it starts when the employee is registered as a participant and ends when the employee does not have an employment relationship, retires or dies or stops working and has transferred his / her rights to another Pension Fund. In brief,

The spread of the Covid-19 Pandemic has had an impact in terms of investment on Bank Kalteng Pension Funds asas a Non-Bank Financial Services Institution Industry (LJNKB) that provides a Defined Benefit Pension Program (PPMP). The impact in terms of investment in the Bank Kalteng Pension Fund is described as follows:

Table. 2 Total Investment of Bank Kalteng Pension Funds January - June 2020 (in Rupiah)

\begin{tabular}{|c|c|}
\hline Month & Total Investment \\
\hline January & $76,155,420,083$ \\
\hline February & $75,462,305,700$ \\
\hline March & $72,862,249,353$ \\
\hline April & $73,518,221,780$ \\
\hline May & $84,460,046,763$ \\
\hline June & $84,955,194,984$ \\
\hline
\end{tabular}

Source: Monthly Financial Reports of Bank Kalteng Pension Funds (January-June) 2020

Based on the table 1 above, it can be seen that the total investment of Bank Kalteng Pension Funds has a downward trend in March and April when compared to JanuaryFebruary As the total investment in March in Central Kalimantan bank pension funds decreased to IDR 72,862,249,353 and in the month of april is IDR 73,518,221,780. Meanwhile, in May-June, the total investment in pension funds has seen an upward trend again, namely in May amounting to IDR 84,460,046,763 and IDR 84,955,194,984 in June. 


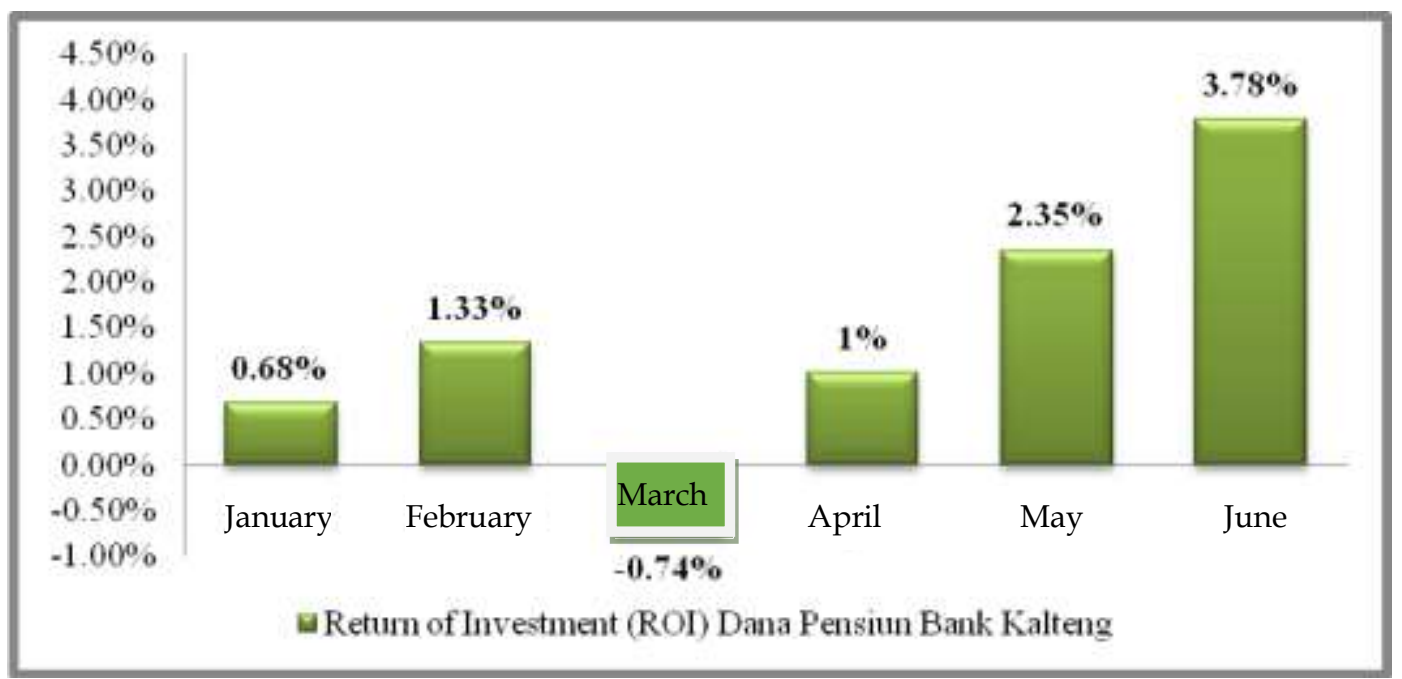

Source: Monthly Financial Reports of Bank Kalteng Pension Funds (January-June) 2020

Figure 1. Return on Investment (ROI) Bank Kalteng Pension Funds January - June 2020

In terms of return on investment (ROI), it can be seen based on graph.1 shows that the ROI of Bank Kalteng Pension Funds experienced a downward trend in March and April when compared to January-February which showed an upward trend from $0.68 \%$ to $1.33 \%$. In addition, it is also seen that the peak of the downward trend in the ROI of Bank Kalteng Pension Funds was in March, which fell to $-0.74 \%$, while in April it rose to $1 \%$ but is still lower than the ROI in February.

As based on the data description above, it can be seen that the impact of the spread of Corona Virus Disease 2019 (COVID-19) has the potential to affect the level of total investment and the Return of Investment (ROI) of Bank Kalteng Pension Funds. Given that the spread of the Covid-19 pandemic began in March 2020 and continues until now. This is in line with the results of interviews with Key Informants of Bank Kalteng Pension Funds, which stated that the trend of increasing or decreasing investment returns and ROI in MarchJune 2020 was influenced by the impact of the spread of the Covid-19 pandemic. As the informant also stated that the decline or increase was triggered by the unstable condition or performance of the company where the investment was due to the impact of the spread of Covid-19.

So that in facing the impact of the spread of Covid-19, the Bank Kalteng Pension Fund implemented it Circular letter S-10 / D.05 / 2020 Year 2020 concerning Countercyclical Policy consisting of 3 (three) provisions, namely relaxation Submission of Periodic Reports, Implementation of Fit and Proper Tests through Video Converence and Shifting Investments to Low Risk Investments.

\subsection{Submission of Periodic Reports on Bank Kalteng Pension Funds}

Based on the Countercylical Policy regarding the submission of periodic reports on pension funds to the Financial Services Authority, Bank Kalteng Pension Fund has submitted monthly reports in accordance with the policy OJK Circular Letter Number S-7 / D.05 / 2020 Year 2020. 
Table 3. Time to Submit Periodic Reports of Bank Kalteng Pension Funds in Month (January-June) 2020

\begin{tabular}{|c|c|c|}
\hline Report Type & Report Period & Report Submission \\
\hline \multirow{4}{*}{ Monthly report } & January 2020 & February 7th \\
\cline { 2 - 3 } & February 2020 & March 6, 2020 \\
\cline { 2 - 3 } & March 2020 & 18 April 2020 \\
\cline { 2 - 3 } & April 2020 & 14 May 2020 \\
\cline { 2 - 3 } & May 2020 & 11 June 2020 \\
\cline { 2 - 3 } & June 2020 & 9 July 2020 \\
\hline
\end{tabular}

Source: Monthly Financial Reports of Bank Kalteng Pension Funds (January-June) 2020

As based on table 3 above, for the March period report, the Bank Kalteng Pension Fund is submitted on April 18, 2020, past the deadline of 4 (four) days from the submission of the report based on the provisions. However, in this case the submission of periodic reports on Bank Kalteng Pension Funds is still included in the deadline for submission of reports that have been relaxed in accordance with countercyclical policies. Then for the April period report, the Central Kalimantan Bank Pension Fund will be submitted on May 14, 2020, past the time limit of 4 (four) days from the submission of the report based on the provisions. However, in this case the submission of periodic reports on Bank Kalteng Pension Funds is still included in the deadline for submission of reports that have been relaxed in accordance with countercyclical policies. For the May Report, Bank Kalteng Pension Fund will be submitted on June 11, 2020, after the deadline of 1 (one) day from the submission of the report based on the provisions. So for the reporting period of May, the Bank Kalteng Pension Fund is included in the deadline for submitting reports that have been relaxed in accordance with countercyclical policies. Meanwhile, the report for the period of June has been submitted to the Bank Kalteng Pension Fund in a timely manner, namely on July 9, 2020 in accordance with the provisions. Bank Kalteng Pension Fund is included in the deadline for submission of reports that have been relaxed in accordance with countercyclical policies. Meanwhile, the report for the period of June has been submitted to the Bank Kalteng Pension Fund in a timely manner, namely on July 9, 2020 in accordance with the provisions. Bank Kalteng Pension Fund is included in the deadline for submission of reports that have been relaxed in accordance with countercyclical policies. Meanwhile, the report for the period of June has been submitted to the Bank Kalteng Pension Fund in a timely manner, namely on July 9, 2020 in accordance with the provisions.

Informants who were interviewed stated that there were no problems related to submitting monthly reports to the Financial Services Authority (OJK). As the Bank Kalteng Pension Fund has fulfilled its reporting obligations and there may be some reports that are late in submitting so that they pass the general provisions of the reporting limit, but this is not a problem because it is still included in the deadline for submission of reports that have been relaxed in accordance with countercyclical policies, namely the form of policies on impact the spread of the Covid-19 pandemic for Pension Funds. As the delay in submitting this is due to the impact of the spread of Covid-19, so that the Pension Fund also experiences difficulties in preparing monthly financial reports, especially in terms of investment calculations.

Apart from that, the informants also said that the obligation of relaxation has helped in administration, namely the obligation to submit reports to the authorities. Given the social restrictions and physical restrictions during the Covid-19 pandemic, the number of employees 
who came to work was limited. Thus, the Pension Fund can still meet periodic reporting obligations whose maturity period is extended.

\subsection{Implementation of Fit and Proper Test}

The fit and proper test is carried out in order to create a healthy Non-Bank Financial Services Institution (LJKNB) industry that is able to provide the best service for the community. Several factors of assessment in carrying out the fit and proper test include competence, integrity and financial reputation.

Regarding the Countercyclical Policy, namely the implementation of a fit and proper test of the main parties of pension funds via video conference, the Central Kalimantan Bank Pension Fund has carried out a fit and proper test based on the approval of the Financial Services Authority (OJK), namely on July 132020 at 09.00 WIB via video conference. As the main parties who undergo the test include members of the Management or Directors, Members of the Supervisory Board and Experts.

Based on the results of the interview, the informant stated that the fit and proper test of the Bank Kalteng Pension Fund on July 13, 2020 had been carried out properly even though it was through online media. In addition, the informant also stated that the countercyclical policy, namely the implementation of fit and proper tests through video conference media greatly helped the participants of the Central Kalimantan Bank Pension Fund in undergoing the test, given the current situation, namely the Covid-19 pandemic which did not support the process of implementing the fit and proper test directly or face to face with the Financial Services Authority.

\subsection{Investment Shift to Low Risk Investments}

Based on Monthly Financial Reports starting from January-June 2020, Bank Kalteng Pension Fund invests in the form of Bonds and Government Securities (SBN). As investment in the form of bonds in the Bank Kalteng Pension Fund, including investment in the financial sector, mining sector, infrastructure-transportation-services sector, various industrial sectors and property-real estate-building construction sectors. The following is a breakdown of the investment appraisal in the form of bonds in the Bank Kalteng Pension Fund:

Table 4. Bank Kalteng Pension Fund Bonds for January-June 2020 (in Rupiah)

\begin{tabular}{|l|c|c|c|}
\hline \multirow{3}{*}{ Month } & \multicolumn{3}{|c|}{$\begin{array}{c}\text { Investment Appraisal Difference (SPI) } \\
\text { Bank Kalteng Pension Fund Bonds } \\
\text { (in rupiah) }\end{array}$} \\
\cline { 2 - 4 } & \multicolumn{2}{|c|}{$(-)$} & $\begin{array}{c}\text { Total } \\
\text { Investment Valuation } \\
\text { Difference }\end{array}$ \\
\hline January & $589,725,000$ & $(60,717,000)$ & $650,442,000$ \\
\hline February & $625,711,000$ & $(63,203,000)$ & $687,914,000$ \\
\hline March & $243,355,000$ & $(572,891,000)$ & $(329,536,000)$ \\
\hline April & $394,242,000$ & $(515,254,000)$ & $(121,012,000)$ \\
\hline May & $395,817,000$ & $(312,145,000)$ & $83,672,000$ \\
\hline June & $500,713,000$ & $(255,648,000)$ & $245,065,000$ \\
\hline
\end{tabular}

Source: Monthly Financial Reports of Bank Kalteng Pension Fund (January-June)

Meanwhile, the details of the investment appraisal in the form of Government Securities (SBN) of Bank Kalteng Pension Fund are as follows: 
Table 5. Government Securities of Bank Kalteng Pension Fund for January-June 2020 (in Rupiah)

\begin{tabular}{|c|c|c|c|}
\hline \multirow{2}{*}{ Month } & \multicolumn{3}{|c|}{$\begin{array}{c}\text { Investment Appraisal Difference (SPI) } \\
\text { Central Kalimantan Bank Pension Fund Government Securities } \\
\text { (in rupiah) }\end{array}$} \\
\hline & $(+)$ & $(-)$ & $\begin{array}{c}\text { Total } \\
\text { Investment Valuation } \\
\text { Difference }\end{array}$ \\
\hline January & - & $(568,935,000)$ & $(568,935,000)$ \\
\hline February & - & $(805,459,000)$ & $(805,459,000)$ \\
\hline March & - & $(2,314,405,000)$ & $(2,314,405,000)$ \\
\hline April & - & $(1,886,547,000)$ & $(1,886,547,000)$ \\
\hline May & - & $(1,402,355,000)$ & $(1,402,355,000)$ \\
\hline June & - & $(977,855,000)$ & $(977,855,000)$ \\
\hline
\end{tabular}

Source: Monthly Financial Reports of Bank Kalteng Pension Funds (March-June) 2020

Based on table above, investment valuation in Bank Kalteng Pension Fund in the form of Bonds and Government Securities (SBN) in March experienced a significant decline, namely in February Bonds amounting to Rp 687,914,000 and SBN amounting to (- Rp $805,459,000)$ to become amounting to $(-\mathrm{Rp} 329,536,000)$ for Bonds and $(-\mathrm{Rp} 2,314,405,000)$ for SBN in March. As related to investment in the form of bonds and government securities which experienced a significant decline in March, informants stated that this was due to a decrease in fair value due to unstable market conditions or companies affected by the Covid-19 Pandemic.

In addition, regarding the decline in investment in the form of bonds and government securities, the informant stated that this was due to new purchases of Government Bonds and Government Securities (SBN) that were not in accordance with the plan at the beginning of the year and the business plan in the year. 2020, thus affecting the coupons received by the Central Kalimantan Bank Pension Fund and experiencing a slight decline but not too significant.

Then based on the results of the interview, the informant also stated that in facing the impact of the spread of the Covid-19 pandemic, the Central Kalimantan Bank Pension Fund still allocates investment in the form of Government Bonds and Government Securities $(\mathrm{SBN})$. As investment in government bonds and government securities is a low risk investment instrument and is expected to be able to protect the investment value of the Bank Kalteng Pension Fund in an unstable economic situation due to the Covid-19 Pandemic. In addition, the Central Kalimantan Bank Pension Fund will also increase the active trading of Government Securities (SBN) with the aim of optimal investment returns.

\section{Conclusion}

The Covid-19 pandemic has had an impact on various industrial sectors including the Bank Kalteng Pension Fund as one of the Non-Bank Financial Services Institutions (LJKNB) industrial sectors. As in order to deal with these impacts, the OJK issued a policy for pension funds, namely the Countercyclical Policy. Based on the research results, the Bank Kalteng Pension Fund has implemented the policies of the Financial Services Authority namelyCircular Number S-10 / D.05 / 2020 concerning Policy Countercyclical for Pension Funds in the context of dealing with the impact of the spread of COVID-19. As stipulated in the countercyclical policy that has been implemented by the Bank Kalteng Pension Fundincluding relaxation of periodic reports submission, implementation of fit and proper tests through video conferences and shifting investment to low risk investments in the form of 
bonds and government securities. In this implementation, the relaxation policy issued by the Financial Services Authority is deemed to have helped the Central Kalimantan Bank Pension Fund in the administration and investment fields. Besides implementing countercyclical policies in dealing with the impact of the spread of Covid-19, in carrying out operational management of the Pension Fund, it is still necessary to maintain efficiency and fairness by upholding the principle of prudence.

\section{References}

Khaerul Umam dan Herry Sutanto. (2017). Cetakan Pertama, CV Pustaka Setia, Bandung. Kompas.com. Update Virus Corona 2 Maret: 89.212 Orang di 68 Negara Terinfeksi. Diakses dari https://sains.kompas.com/read/2020/03/02/170200123/update-virus-corona-2maret-89212-orang-di-68-negara-terinfeksi?page=all,

Kompas.com. WHO Umumkan Virus Corona sebagai Pandemi Global. Diakses dari https://www.kompas.com/sains/read/2020/03/12/083129823/who-resmi-sebutviruscorona-covid-19-sebagai-pandemi-global?page=all

Laporan Keuangan Bulanan Dana Pensiun Bank Kalteng. Data Return of Investment (ROI) Dana Pensiun Bank Kalteng dari Bulan Januari-Juni Tahun 2020

Laporan Keuangan Bulanan Dana Pensiun Bank Kalteng. Data Total Investasi Dana Pensiun Bank Kalteng dari Bulan Januari-Juni Tahun 2020

Laporan Keuangan Bulanan Dana Pensiun Bank Kalteng. Data Tanda Terima Pelaporan Laporan Keuangan Bulanan Dana Pensiun Bank Kalteng kepada OJK dari Bulan Januari-Juni Tahun 2020

Laporan Keuangan Bulanan Dana Pensiun Bank Kalteng. Data Selisih Penilaian Investasi (SPI) Obligasi Dana Pensiun Bank Kalteng dari Bulan Januari-Juni Tahun 2020

Laporan Keuangan Bulanan Dana Pensiun Bank Kalteng. Data Selisih Penilaian Investasi Surat Berharga Negara Dana Pensiun Bank Kalteng dari Bulan Januari-Juni Tahun 2020

Majalah info Dana Pensiun. Edisi (Mei-Juni 2020). Mengukur Dampak COVID-19 pada Industri Perbankan

Oe, H and Week, M. (2020). How to Support Vulnerable Citizens during the COVID-19 Lockdown: A Community Initiative from Ubiquitous Network Perspectives. Budapest International Research and Critics Institute-Journal (BIRCI-Journal).P. 1369-1377

Peraturan OJK Nomor 3 Tahun 2015 tentang Investasi Dana Pensiun

Saleh,A.et al. (2020). Challenges and Opportunities for Community Empowerment Practices in Indonesia during the Covid-19 Pandemic through Strengthening the Role of Higher Education. Budapest International Research and Critics Institute-Journal (BIRCI Journal). P. 1105-1113

Setyo Wijayanto. (2015). Strategi Jitu Inveetasi Obligasi Korporasi. Percetakan PT Gramedia, Jakarta.

Susilawati et al. (2020). Impact of COVID-19's Pandemic on the Economy of Indonesia. Budapest International Research and Critics Institute-Journal (BIRCI-Journal). P. 11471156.

Sugiyono. (2011). Metode penelitian pendidikan. Bandung: Alfabeta.

Surat Edaran Nomor S-10/D.05/2020 tentang Kebijakan Countercylical

Undang-undang Republik Indonesia Nomor 11 Tahun 1992 tentang Dana Pensiun

Moleong, Lexy J. (2016). Metodologi Penelitian Kualitatif: Edisi Revisi. Cetakan ketigapuluhlima, PT Remaja Rosdakarya Offset, Bandung.

Worldometers. Report Corona Virus Cases. Diakses dari https://www.worldometers.info/coronavirus/ pada tanggal 16 Agustus 2020 